\title{
ANALISIS KELAYAKAN KOLAM RENANG
}

\author{
Chindi Aran Neri
}

PJKR FKIP UNIB, e-mail: Chindyarannery@gmail.com

\author{
Sugiyanto \\ Universitas Bengkulu \\ Ari Sutisyana \\ Universitas Bengkulu
}

\begin{abstract}
Abstrak
Penelitian ini bertujuan untuk mengepaluasi secara faktual kalayakan kolam renang. dalam hal ini jenis penelitian yang digunakan adalah deskriptif kualitatif. Subjek penelitian yaitu kolam renang Intan Permata, Hamtian, Grage Hotel (Horizon), Teluk Benaol Indah (TBI), Putri, dan Raflesia. Dari ke enam subjek penelitian tersebut adalah kolam renang pengolaan data menggunakan instrumen kuisioner. hasil penelitian bahwa 56,66\% lahan parkir layak dan 19,99\% lahan kurang layak, 46,66\% kenyamanan parkir sangat baik dan 29,99\% cukup aman, pengolaan parkir 53,33\% Sangat baik, $19,99 \%$ cukup baik. 50,00\% keadaan kolam sangat baik, 23,33\% keadaan cukup baik. $36,66 \%$ pengolaan kolam sudah baik. 39,99\% kadar air sangat baik dan 30,00\% kebersihan cukup baik. Kesimpulan : kolam renang sudah memiliki standar kolam yang memadai, pemilik kolam renang cukup maksimal dalam panataan sarana prasarana kolam renang, dan bisa mengembangkan kondisi kolam renang untuk menarik minat para pengunjung. Saran : Kepada pengurus/karyawan yang selalu memperhatikan keadaan kolam dan pengunjung hendaknya selalu menjaga kebersihan dan senatiasa berkunjung untuk rekreasi.
\end{abstract}

Kata Kunci : Kelayakan Kolam Renang.

\begin{abstract}
This study aims to evaluate factually the feasibility of swimming pools. In this case the type of research used is descriptive qualitative. The research subjects are Intan Permata swimming pool, Hamtian, Grage Hotel (Horizon), Benaol Indah Bay (TBI), Princess, and Raflesia. Of the six subjects of the study is a pool of data processing using a questionnaire instrument. Result of research that $56,66 \%$ of parking area is feasible and $19,99 \%$ land less feasible, $46,66 \%$ comfort of parking is very good and $29,99 \%$ is safe, parking management 53,33\% Very good, 19,99\% good enough. $50.00 \%$ the state of the pool is very good, $23.33 \%$ the situation is quite good. $36.66 \%$ of the pool management is good. 39,99\% very good water content and 30,00\% cleanliness good enough. Conclusion: The swimming pool already has an adequate pool standard, the owner of the swimming pool is maximized in swimming pool infrastructure, and can develop the condition of the swimming pool to attract the visitors. Suggestion: To the
\end{abstract}


management / employees who always pay attention to the condition of the pool and visitors should always keep clean and always visit for recreation.

Keywords: Eligibility Pool Swimming.

\section{PENDAHULUAN}

Olahraga renang merupakan aktivitas yang dilakukan di air dengan berbagai macam bentuk dan gaya yang sudah sejak lama dikenal banyak memberikan manfaat kepada manusia. Manfaat yang ada pada aktivitas olahraga renang tersebut antara lain adalah untuk memelihara dan meningkatkan kebugaran, menjaga kesehatan tubuh, untuk keselamatan diri, untuk membentuk kemampuan fisik seperti daya tahan, kekuatan otot serta bermanfat pula bagi perkembangan dan pertumbuhan fisik anak, untuk sarana dan prasarana pendidikan, rekreasi, rehabilitasi serta prestasi.

Keberhasilan salah satu kolam renang akan tergantung pada penerapan atau pelaksanaan manajemen. Manajemen adalah kemampuan dan keterampilan khusus untuk melakukan suatu kegiatan bersama orang lain atau melalui orang lain dalam mencapai tujuan organisasi. Hersey dan Blanchard (1982:3). Memberi arti pengelolaan sebagai berikut: "management as working with and through individuals and groups to accomplish organizational goals"(pengelolaan kelompok dengan maksud untuk mencapai tujuan-tujuan organisasi). Stoner mengemukakan bahwa " management is the process of planning, organizing, leading and controlling the efforts of organizing members and of using all other organizational resources to ac hieve stated organizational goals" dalam Sudjana (1992:12).
Ketersediaan fasilitas olahraga merupakan kebutuhan dasar masyarakat untuk melakukan aktivitas olahraga renang. Semakin banyak fasilitas, maka akan semakin mempermudah masyarakat dalam menggunakan dan memanfaatkan fasilitas tersebut untuk kepentingan olahraga. Dengan demikian fasilitas dapat mempengaruhi partisipasi masyarakat dalam berolahraga.

\section{METODE}

Berdasarkan tujuan penelitian ini adalah penelitian deskriptif Kualitatif. Menurut Arikunto (2010 : 3) penelitian deskriptif Kualitatif adalah merupakan penelitian yang dimaksud untuk menyelidiki keadaan, kondisi atau hal lain-lain yang sudah disebutkan, yang hasilnya dipaparkan dalam bentuk laporan penelitian. Penelitian tentang kelayakan kolam renang adalah penelitian yang bersifat pengembangan dalam penelitiannya yang tidak perlu merumuskan hipotesisnya. Data yang di peroleh berupa kata-kata, gambar dan sumber lain yang berkaitan dengan penilitian. Data- data tersebut di dapat dari observasi, wawancara, dokumen pribadi, dan dokumen-dokumen resmi.

Pengambilan subjek dalam penelitian ini menggunakan teknik purposive, yaitu dengan memilih orangorang yang dianggap tahu tentang fokus masalah seperti pemilik kolam, pengurus kolam, dan masyarakat atau pengunjung yang ada di kolam Kota Bengkulu berjumlah 6 Kolam Renang. Kemudian dipadukan dengan teknik snowball sampling, yaitu meminta informan sebelumnya tersebut untuk menunjuk 
orang-orang yang dapat dijadikan informan.

Menurut Sugiyono (2014 : 308), teknik pengumpulan data merupakan langkah yang paling utama dalam penelitian, karena tujuan utama dari penelitian adalah utnuk mendapatkan data yang memenuhi standar peneliti mengunakan teknik observasi, kuesioner, wawancara, dokumentasi, sehingga data yang terkumpul akurat dan terpercaya sesuai yang dibutuhkan. Langkah awal yang dilakukan peneliti meliputi observasi pertama lokasi kolam yang akan dijadikan tempat, kedua membuat jadwal wawancara dan dokumentasi, sehingga dengan jadwal yang ditentukan penelitian dapat berjalan dengan lancar serta mendapatkan informasi yang di butuhkan.

Instrumen penelitian utama yang digunakan dalam penelitian ini adalah peneliti sendiri dengan melakukan wawancara mendalam dengan panduan pertanyaan yang telah disiapkan oleh peneliti tentang hal-hal pokok yang diketahui. Panduan pertanyaan ini mempermudah peneliti dalam mengarahkan proses wawancara dan alat bantu yang digunakan dalam metode wawancara adalah catatan-catatan wawancara. Selain itu insturmen dalam penelitian ini meliputi observasi dengan mendata sarana dan prasarana kolam renang Kota Bengkulu. Setelah wawancara yang dilakukan melalui pedoman kisi - kisi yang telah di buat peneliti mencari tau tentang pengelolaan fasilitas kolam renang dan mengambil gambar-gambar yang berhubungan kelayakan kolam renang di tempat tersebut.

\section{HASIL PEMBAHASAN}

Kolam renang merupakan salah satu objek wisata yang sering di kunjungi oleh berbagai masyarakat untuk mencari kesenangan. Oleh karena itu pengelolaan kolam harus tetap di jaga demi kenyamanan pengunjung. Muai dari kelayakan atau pengolaan parkir, luar perkarangan kolam, kebersihan kolam, maupun keadaan lainnya. Dilihat dari kelayakan, kenyaman serta pengolaan parkir di dapat hasil bahwa 56,66\% lahan parkir layak digunakan dan 19,99\% lahan kurang layak digunakan menurut beberapa pengunjung, kemudian $46,66 \%$ kenyamanan parkir sangat baik dan 29,99\% cukup aman, serta pengolaan parkir dengan hasil 53,33\% Sangat baik, $19,99 \%$ cukup baik. Selain pengolaan parkit yang harus di perhatikan adalah pengolaan kolam serta bagian dan alat pendukung lainnya. 50,00\% keadaan kolam sangat baik, 23,33\% keadaan cukup baik. Pengolaan air pada kolam harus selalu diperhatikan mulai dari kadar air ,kebersihan kolam serta kebersihan sekeliling kolam. Hasil menunjukan bahwa $36,66 \%$ pengolaan kolam sudah baik dilakukan oleh pihak kolam. Menurut beberapa masyarakat kadar air kolam dan kebersihannya 39,99\% kadar air sangat baik dan 30,00\% kebersihan cukup diperhatiakn oleh pihak kolam. Kelayakan kolam juga dipengaruhi oleh pelayanan serta pengawasan yang diberikan oleh pihak kolam maupun petugas kolam. Kelebihannya juga kolam bisa menyediakan alat-alat $\mathrm{p} 3 \mathrm{k}$ serta adanya tempat duduk santai dipinggiran kolam yang bisa membuat ketetarikan kepada penggunjung.

\section{Pembahasan}

Berdasarkan hasil penelitian kelayakan kolam yang baik itu kolam terletak ditempat strategis, misalnya tempat kolam yang terletak di pinggir jalan sehingga masyarakat mudah untuk mengunjungi kolam renang. Kolam juga 
harus selalu diperhatikan kebersihannya mulai dari jernihnya air kolam, kadar air kolam, serta bagian sekeliling kolam yang menarik minat pengunjung. Selain itu juga pelayanan dan pengawasan pada pengunjung harus di optimalkan agar dapat menambah minat pengunjung. Dilihat dari observasi Kelayakan Kolam renang bahwa sebagaian kolam sudah memiliki standar kolam renang yang memadai walaupun sedikit memiliki kendala. Namun dari ke enam kolam renang yang sudah di observasi masih banyak kendala-kendala atau kurangnya potensi keadaan lingkungan kolam renang, dikarenakan bahwa sarana dan prasarana, fasilitas kolam yang belum memiliki standar kelayakan.

Menurut Harzuki (2012 : 187 ) sarana dan prasarana fasilitas tersebut memiliki ciri -ciri yang harus di ketahui oleh kelolaan dan layak untuk kita lakukan maka dari itu untuk bisa beroperasi pada jam yang di tentukan pada setiap harinya dalam melalui pengoperasian fasiltas yang dapat mengahasilkan banyak manfaat terhadap kelayakan kolam renang.

\section{PENUTUP}

\section{Simpulan}

Berdasarkan hasil penelitian dan pembahasan tentang kelayakan kolam dapat disimpulkan bahwa : kolam renang sudah memiliki standar kolam yang memadai dapat di lihat dari kondisii layaknya keterbatasan dengan keadaan sekarang, pemilik kolam renang dapat dikatakan cukup maksimal dalam panataan sarana prasarana kolam renang yang telah memadai, dan bisa mengembangkan kondisi kolam renang untuk menarik para pengunjung yang sentiasa dapat bisa berkunjung ke kolam renang yang terdekat, maka dari itu pengunjung dapat bisa mengetahui kolam renang yang memiliki kelayakan dan tidak layaknya kolam.

\section{Saran}

Dari kesimpulan dapat di ajukan saran sebagai berikut :

1. Kepada pengurus/karyawan yang selalu memperhatikan keadaan kolam , pelayanan, serta pengawasan kepada para pengunjung.

2. Untuk pengunjung hendaknya selalu menjaga kebersihan dan senatiasa berkunjung untuk rekreasi.

\section{DAFTAR PUSTAKA}

Leo, Arwin, dan Syafrial. 2017. "Profil Kondisi Fisik Pemain Sepak Bola SMA Negeri 1 Kaur" Jurnal Kinestetik, Vol. 1 (1).

Sugiyono.(2014). Metode Penelitian Kombinasi (Mixed Methods). Bandung: Alfabeta.

Sudjana.(1992). Manajemen Pendidikan Luar Sekolah. Bandung: Nusantara Press-Yayasan Islam Nusantara.

Suharsimi Arikunto. (2010). Prosedur Penelitian. Jakarta: PT Rineka Cipta

Tangkudung, James. (2012). Kepelatihan Olahraga Pembinaan Prestasi Olahraga. Jakarta: Cerdas jaya (2016).Macam-macam Metodologi Penelitian. Jakarta: Lensa Media Pustaka Indonesia 